\title{
Estimation of Living Stature from Foot Dimensions in Uturu Indigenes of Abia State, Nigeria
}

\author{
Loveday Ese Oghenemavwe, Oghenekome Blessing Egwede
}

\section{ABSTRACT}

Stature estimation is an important process in human identification. The aim of the study was to derive regression formulae for estimation of stature from foot dimensions in Uturu indigenes of Abia State. The sample consists of 150 subjects comprising of 69 males and 81 females between 18 to 50 years of age. The parameters measured were age, stature, foot length and foot width. The mean age, stature, foot length and foot width were $29.78 \pm 1.08$ years, $1738.26 \pm 9.34 \mathrm{~mm}, 261.53 \pm 2.01 \mathrm{~mm}, 84.53 \pm 0.94 \mathrm{~mm}$ for males and 27.04 \pm 0.89 years, $1648.64 \pm 7.61 \mathrm{~mm}, 242.36 \pm 1.80 \mathrm{~mm}, 76.14 \pm 0.72 \mathrm{~mm}$ for females respectively. The highest correlation was found between the stature and foot length in males $(r=0.68)$. Regression formulae were $\mathrm{St}=$

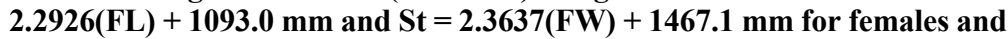
$\mathrm{St}=3.1687(\mathrm{FL})+909.54 \mathrm{~mm}$ and $4.6857(\mathrm{FW})+1342.20 \mathrm{~mm}$ for males. The foot length is a more reliable for estimating stature in Uturu indigenes of Abia.

Keywords: Foot dimensions, regression formulae, stature, Uturu.

Submitted: January 5, 2022

Published: February 10, 2022

ISSN: 2593-8339

DOI: 10.24018 /ejmed.2022.4.1.1191

\section{E. Oghenemavwe*}

Department of Anatomy, Faculty of Basic Medical Sciences, College of Health Sciences, University of Port Harcourt, Choba, Nigeria. (e-mail:

loveday.oghenemavwe@ uniport.edu.ng)

O. B. Egwede

Anatomy Department, Faculty of Basic Medical Sciences, College of Medicine and Health Sciences, Gregory University, Nigeria.

(e-mail: egwedeblessing@gmail.com)

*Corresponding Author

\section{INTRODUCTION}

Stature is the natural height of a person in an upright position. Estimation of stature is an important parameter in identification of persons in forensic context [1], [2]. It is among the big four questions asked in forensic anthropology when trying to unveil the identity of an individual; the others are sex, age and ancestry [1]. The historical background to stature estimation began with the work of Vitruvius promoted by Leonado da Vinci who proposed that the human body is in proportions. These proportions where illustrated in his famous art work "the Vuvitrius man" [3].

Over the years, researchers have tried to formulate methods for the estimation of stature to aid the process of identification of persons. These methods could either be anatomical or mathematical methods. Anatomical methods estimate the total height and was first formulated by Dwight in 1894 , the procedure for estimation was further modified by Fully [4]. It involves the summation of the height of the cranium, vertebra column, femur, tibia, talus and calcaneus. The major setback to this method is that in most case all these bones are not available for the estimation of the needed stature. The mathematical method involves the use of one or more bones to estimate the stature of a person through the formulation of regression formulae [5]. The application of predictive regression models is now so widely used by forensic scientists as some parts of the body could easily to use for predictive anthropometry of another part, for example the hand and foot dimensions could be used to estimate stature [6]-[12].

Several studies have shown that for regression formula to be effective it should be sex and population specific due to interplay of genetic and environmental factors that could cause variations within and between populations [13]-[18]. This is the main motivation for this study as Nigeria has over 250 ethnic groups with over 500 sub-ethnic population and languages [19]. Most studies on stature estimation in Nigeria appear to be over generalized and do not adequately capture the sub-ethnic groups which are mainly homogenous population [20]-[23].

The Uturu people of Abia State are a sub-ethnic population within the Igbo ethnic group of Nigeria. It is made up of several sub-urban settlements with a growing population of about 40,000 people [24]. Presently, there is paucity of information on the relationship between stature and foot dimensions amongst this group. Developing a regression model for this population would contribute immeasurably to easy identification process. Therefore, the aim of the study was to establish the relationship between living stature and foot dimensions through the formulation of regression formulae. 


\section{Materials AND Methods}

One hundred and fifty (sixty-nine males and eighty-one females) Uturu indigenes between the ages of 18 to 50 participated in the study. The inclusion criteria included that both parents and grandparents of participants must be from Uturu. Participants with foot deformity were excluded and those below the age of 18 years and above 50 years were also excluded from the study. The study was approved by the Research Ethics Committee of College of Medicine and Health Gregory University of Uturu Abia State. Written informed consents were obtained from participants after the purpose of the study and data collection procedure was explained to them. The following parameters were measured.

\section{A. Stature}

This was taken using a stadiometer. The participants stood erect, barefooted on the level platform of the stadiometer such that the back of their head, shoulder blade, buttocks and heels touched the bar of the stadiometer. Participants were asked to relax with arms hanging by the side. Care was taken to avoid a sagging position.

\section{B. Foot Length}

This was taken using digital vernier caliper. It is the distance from the most prominent part of the heel to the most distal part of the longest toe (great or second toe).

\section{Foot Width}

The widest point across the foot was taken with a digital vernier caliper. It is the distance between the most prominent point on the medial aspect of head of first metatarsal and the most prominent point on the lateral aspect of head of fifth metatarsal.

The right foot was used for all measurements, and this was taken thrice, and the average recorded to minimize errors.

\section{Statistical Analysis}

The data were analyzed with Microsoft Excel Tool Pak version 2010 and Statistical package for the Social Sciences version 23. Descriptive analyses and regression models for estimation of stature and tests of correlation were done.

\section{RESUltS}

The results are presented in Tables I to IV and Fig. 1 to 6. As shown in Table I, the mean age, stature, foot length and foot width for all participant combined irrespective of sex were 28.30 years, $1689.07 \mathrm{~mm}, 251.18 \mathrm{~mm}$ and $80.00 \mathrm{~mm}$ respectively. Tables II and III showed descriptive statistics of measured parameters for females and males. The mean values for stature, foot length and foot width were higher in males. Table III showed descriptive statistics of measured parameters for male subjects. Correlation coefficient, regression formulae, test of correlation and scatter plots are presented in Table IV and Fig. 1 to 6.
TABLE I: DESCRIPTIVE STATISTICS OF MEASURED PARAMETERS FROM ALL SUBJECTS

\begin{tabular}{lcccccc}
\multicolumn{7}{c}{ PARAMETERS FROM ALL SUBJECTS } \\
\hline \hline Parameter & Mean & SEM & SD & Var & Min & Max \\
\hline \hline Age (yrs) & 28.30 & 0.68 & 8.38 & 70.29 & 18.00 & 49.00 \\
Stature & 1689.87 & 6.96 & 85.29 & 7273.81 & 1440.00 & 1950.00 \\
$(\mathrm{~mm})$ & & & & & & \\
FL (mm) & 251.18 & 1.55 & 18.95 & 358.99 & 192.80 & 305.49 \\
FW (mm) & 80.00 & 0.68 & 8.27 & 68.41 & 57.26 & 101.76 \\
\hline \hline SEM = Standard error of mean, SD = standard deviation, Var = variance, \\
Min = minimum, Max = maximum, FL = Foot length, FW = Foot width
\end{tabular}

TABLE II: DESCRIPTIVE STATISTICS OF MEASURED PARAMETERS FOR FEMALE SUBJECTS

\begin{tabular}{lcccccc}
\hline \hline Parameter & Mean & SEM & SD & Var & Min & Max \\
\hline \hline Age (yrs) & 27.04 & 0.89 & 7.99 & 63.86 & 18.00 & 49.00 \\
Stature & 1648.64 & 7.61 & 68.50 & 4691.88 & 1440.00 & 1820.00 \\
$(\mathrm{~mm})$ & & & & & & \\
FL (mm) & 242.36 & 1.80 & 16.16 & 261.25 & 192.80 & 279.87 \\
FW (mm) & 76.14 & 0.72 & 6.51 & 42.43 & 57.26 & 92.85 \\
\hline \hline
\end{tabular}

SEM = Standard error of mean, $\mathrm{SD}=$ standard deviation, Var = variance, $\mathrm{Min}=$ minimum, $\mathrm{Max}=$ maximum, $\mathrm{FL}=$ Foot length, $\mathrm{FW}=$ Foot width

TABLE III: DESCRIPTIVE STATISTICS OF MEASURED PARAMETERS FOR MALE SUBJECTS

\begin{tabular}{lcccccc}
\hline \hline Parameter & Mean & SEM & SD & Var & Min & Max \\
\hline \hline Age (yrs) & 29.78 & 1.04 & 8.65 & 74.76 & 18.00 & 49.00 \\
Stature & 1738.26 & 9.34 & 77.57 & 6017.52 & 1570.00 & 1950.00 \\
$(\mathrm{~mm})$ & & & & & & \\
FL $(\mathrm{mm})$ & 261.53 & 2.01 & 16.67 & 277.76 & 221.40 & 305.49 \\
FW $(\mathrm{mm})$ & 84.53 & 0.94 & 7.84 & 61.41 & 67.21 & 101.76 \\
\hline \hline
\end{tabular}

SEM $=$ Standard error of mean, $\mathrm{SD}=$ standard deviation, Var $=$ variance, Min $=$ minimum, $\mathrm{Max}=$ maximum, $\mathrm{FL}=$ Foot length, $\mathrm{FW}=$ Foot width

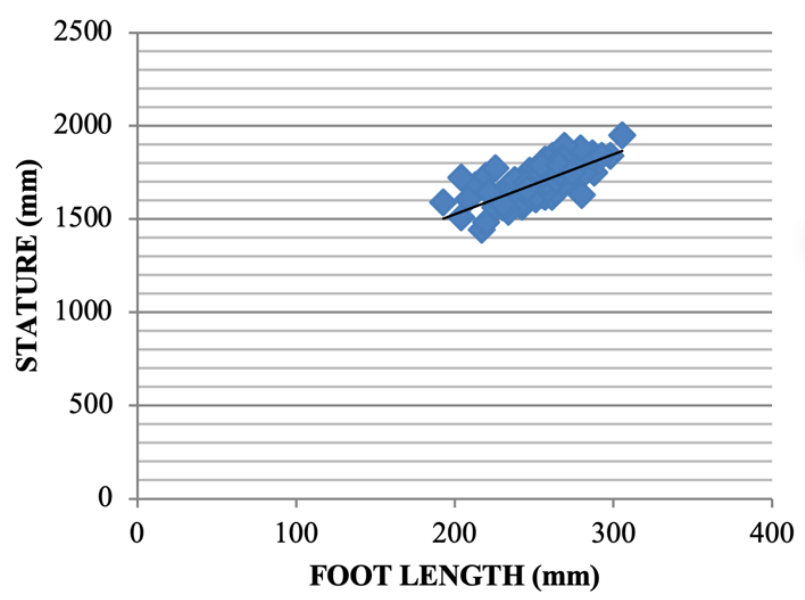

Fig. 1. Scatter plot of stature against foot length for all subjects.

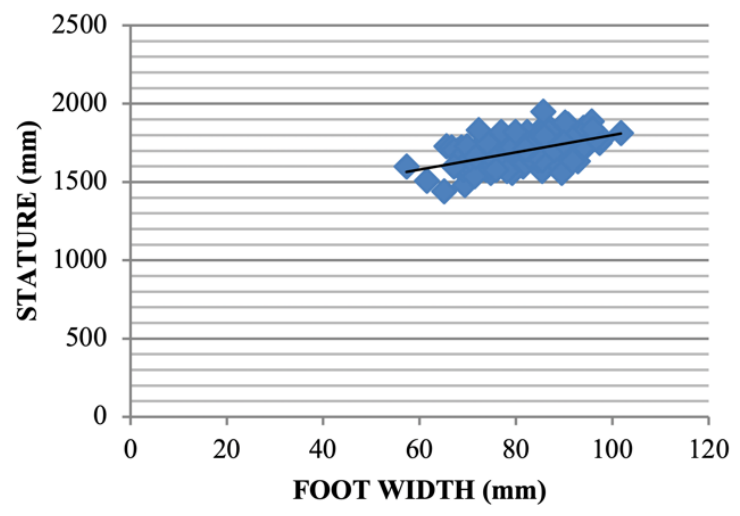

Fig. 2. Scatter plot of stature against foot width for all subjects. 
TABLE IV: PEARSON'S CORRELATION, TEST OF SIGNIFICANCE AND REGRESSION MODEL FOR STATURE ESTIMATION FROM FOOT LENGTH AND FOOT WIDTH

\begin{tabular}{ccccc}
\hline \hline Parameter & Correlation value (r) & P-value & Inference & Regression formula \\
\hline \hline & \multicolumn{2}{c}{ ALL SUBJECTS } \\
\hline Stature vs Foot Length & 0.23 & 0.005 & Correlation is significant & Stature $=3.21189 \mathrm{FL})+883.13$ \\
Stature vs Foot width & 0.53 & 0.000 & Correlation high and very significant & Stature $=5.4619(\mathrm{FW})+1252.9$ \\
\hline \hline & \multicolumn{4}{c}{ FEMALE SUBJECTS } \\
\hline Stature vs Foot Length & 0.54 & 0.00 & Correlation high and significant & Stature $=2.2926(\mathrm{FL})+1093$ \\
Stature vs Foot width & 0.23 & 0.03 & Correlation is significant & Stature $=2.3837(\mathrm{FW})+1467.1$ \\
\hline \hline & \multicolumn{2}{c}{ MALE SUBJECTS } \\
\hline \hline Stature vs Foot Length & 0.68 & 0.00 & Correlation high and very significant & Stature $=3.1687(\mathrm{FL})+909.54$ \\
Stature vs Foot width & 0.47 & 0.00 & Correlation is significant & Stature $=4.6857(\mathrm{FW})+1342.2$ \\
\hline \hline
\end{tabular}

\section{Discussion}

This study has investigated the relationship between living stature and foot length and width among Uturu indigenes of Abia State Nigeria. There is positive significant correlation between stature, foot length and width in the studied population. Several studies on the estimation of stature using foot measurements have shown the human feet to be reliable estimate of stature in the forensic identification [6], [7], [9], [11], [23], [25], [26]. The application of predictive regression models has been used by anthropologists to accurately predict stature using anthropometric measurements of body parts such as foot length and breadth [9], [12], [26].

In the current study, males had higher anthropometric dimensions compared to the females (Stature $=1738.26$ $\pm 9.34 \mathrm{~mm}, \mathrm{FL}=261.53 \pm 2.01 \mathrm{~mm}, \mathrm{FW}=84.53 \pm 0.94 \mathrm{~mm}$ for males and Stature $=1648.64 \pm 7.61 \mathrm{~mm}, \mathrm{FL}=242.36 \pm 1.80$ $\mathrm{mm}, \mathrm{FW}=76.14 \pm 0.72 \mathrm{~mm}$ for females). These findings are in agreement with related studies by [11], [26]-[28]. The differences could be attributed to the fact that limb growth in females usually ends quickly compared to males as a result of a quicker onset of pubertal changes. The foot dimensions in our study were similar to the result of [29], they reported the average values of the right foot length for Nigerians were 27.1 $\pm 1.3 \mathrm{~cm}$ and $25.0 \pm 1.1 \mathrm{~cm}$ for males and females, and the right foot breadth were $9.8 \pm 0.5 \mathrm{~cm}$ and $8.9 \pm 0.5 \mathrm{~cm}$ for males and females respectively.

Correlation of stature with foot length was most significant in males $(\mathrm{r}=0.68, \mathrm{p}<0.01)$ compared to females $(\mathrm{r}=0.54$, $\mathrm{p}$ $<0.01$ ). Similar findings in previous studies showed high reliability of foot length in the estimation of stature, however, this study had lower correlation coefficients for both sexes compared to these studies, and this could be due to racial and population differences [6], [23], [30].

Foot width (breadth) showed the poorest correlation with stature in this present study in females $(\mathrm{r}=0.23)$. In males, there was significant relationship between stature and foot width. These finding are in concordance with those of [11], [31]. Foot length is more reliable for estimating stature compared to foot width and factor influencing this outcome may need to be further investigated.

The stature estimates obtained using the regression formula derived from this study are the appropriate formulae available for Uturu indigenes as they have been tested randomly in clans of Uturu. The formula for females is $\mathrm{St}=$ $2.2926(\mathrm{FL})+1093.0 \mathrm{~mm}$ and $\mathrm{St}=2.3637(\mathrm{FW})+1467.1 \mathrm{~mm}$ while for male it was $\mathrm{St}=3.1687(\mathrm{FL})+909.54 \mathrm{~mm}$ and $4.6857(\mathrm{FW})+1342.20 \mathrm{~mm}$. Similar studies among the
Gujj's population of India showed stature $=90.275 \pm 2.9$ (FL) [9]. Reference [32] also reported the regression formula to estimate stature from the left foot Indians is $\mathrm{S}=101.96 \pm$ $2.6(\mathrm{FL})$ and Stature $=89.63 \pm 3.6(\mathrm{FL})$ for males and females respectively.

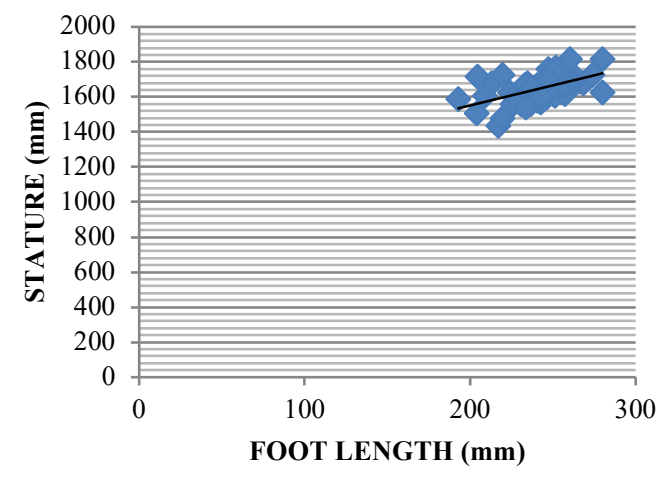

Fig 3. Scatter plot of stature against foot length for female subjects.

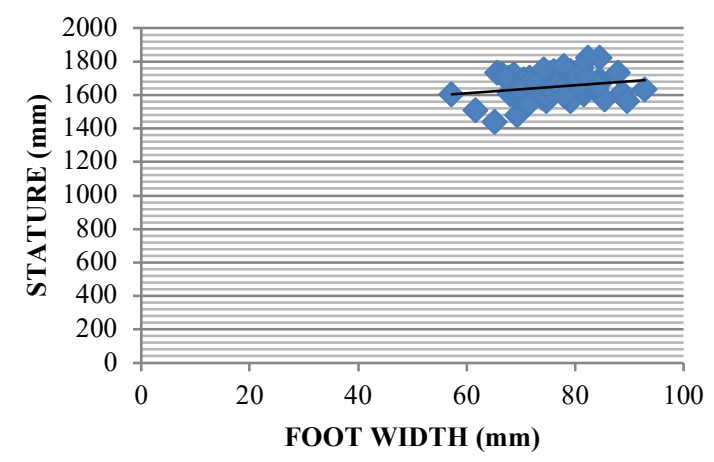

Fig 4. Scatter plot of stature against foot width for female subjects.

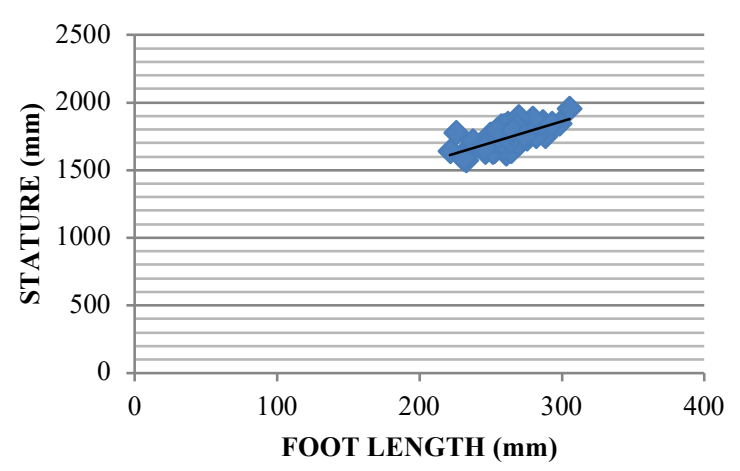

Fig 5. Scatter plot of stature against foot length for male subjects. 


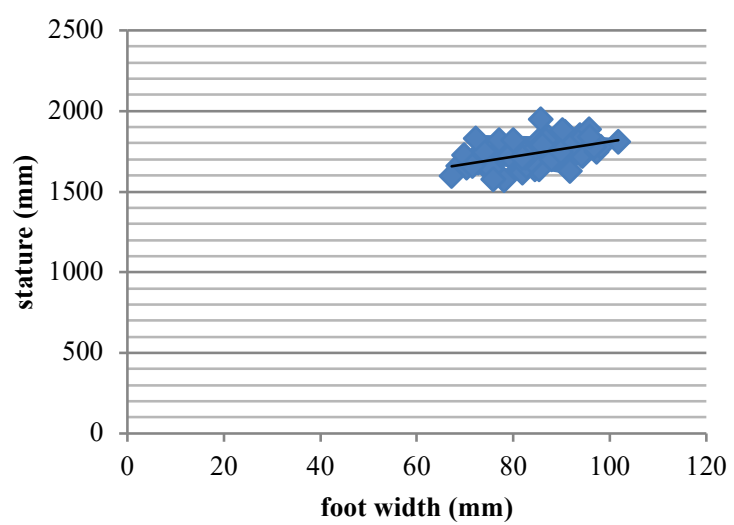

Fig 6. Scatter plot of stature against foot width for male subjects.

\section{CONCLUSION}

Foot length and width correlate with stature and these anthropometric parameters could be used to estimate one another amongst Uturu indigenes. Foot length is much more significant in estimating stature in males compared to their female counterparts. The linear regression formula derived in this study would be useful in estimating the stature of Uturu indigenes of Abia State Nigeria.

\section{ACKNOWLEDGMENT}

We sincerely appreciate the support of Nkechi Nwosu, Amasiatu Valentine, Utoon Amasiatu, Ibinabo Bob-Manuel and Preye Omo-Ebidor for providing the community based support services for the project.

\section{CONFLICT OF INTEREST}

Authors declare that they do not have any conflict of interest.

\section{REFERENCES}

[1] Iscan MY, Steyn M. The human skeleton in Forensic medicine, Springerfiled Illinois USA, 2013.

[2] Ebite L, Ozoko T, Eweka A, Otuaga P, Oni A, Om'Iniabohs F. Height: ulna ratio: A method of stature estimation in a rural community in Edo State, Nigeria. The Internet Journal of Forensic Science. 2003; 3(1).

[3] Polio MV deArchitectura Book III [Internet] 2020. Available from: https://penelope.uchicago.edu/Thayer/E/Roman/Texts/Vitruvius/3*.ht $\mathrm{ml}$

[4] Fully G. New method of determination of the height. Ann. Med. Leg. Criminol. Police. Sci. Toxicol. 1956; 36: 266-273.

[5] Pearson K. Mathematical contributions to the theory of evolution. On the reconstruction of the stature of prehistoric races. Phil. Trans. R. Soc. Lond. A. 1899; 192: 169-244.

[6] Ozden H, Balci Y, Demirustu C, Turgut A, Ertugrul M. Stature and sex estimate using foot and shoe dimensions. Forensic Sc. Internat. 2005; 147: $181-184$.

[7] Krishan K, Sharma A. Estimation of stature from dimensions of hands and feet in a North Indian population. J Forensic Leg Med. 2007; 14(6): 327-32.

[8] Krishan K. Determination of stature from foot and its segments in a North Indian population. Am J Forensic Med and Pathol. 2008; 29: 297-303.

[9] Kanchan T, Menezes RG, Moudgil R, Kaur R, Kotian MS, Garg RK. Stature estimation from foot dimensions. Forensic Sci Int. 2008; 179:(2-3): 241.e1-5.
[10] Krishan K, Kanchan T, Passi N. Estimation of stature from the foot and its segments in a sub-adult female population of North India. J Foot Ankle Res. 2011; 4:24.

[11] Sen J, Ghosh S. Estimation of stature from foot length and foot breadth among the Rajbanshi: an indigenous population of North Bengal. Forensic Sci Int. 2008; 181(1-3): 55.e1-6.

[12] Paul CW, Osuchukwu IW, Aigbogun (Jr) EO, Ekezie J. Stature estimation from foot dimensions of Igbo indigenes of Imo State extraction In Nigeria. Int J. Recent Sci Res. 2018; 9(1): 23323-23327.

[13] Dupertuis CW, Hadden J. On the reconstruction of stature from long bones. Am. J. Phys. Anthropol.1951; 9: 15-54.

[14] Trotter M, Gleser GC. Estimation of stature from long bones of American Whites and Negroes. Am. J. Phys. Anthropol. 1952; 10: 463514.

[15] Olivier G, Aaron C, Fully G, Tissier G. New estimations of stature and cranial capacity in modern man. J. Hum. Evol. 1978; 7: 513-518.

[16] Lundy JK Regression equations for estimating living stature from long limb bones in the South African Negro. S. Afr. J. Sci. 1983; 79: 337338.

[17] Dayal MR, Steyn M, Kuykendall KL. Stature estimation from bones of South African Whites. South African Journal of Science. 2008; 104: 124-128

[18] Lundy JK, Feldesman MR. Revised equations for estimating living stature from long bones of the South African Negro. S. Afr. J. Sci. 1987; 83: 54-55.

[19] University of Birmingham. CIFORB Country Profile - Nigeria. [Internet] $2021 \quad$ Available from: https://www.birmingham.ac.uk/Documents/college\%20artslaw/ptr/cif orb/resources/Nigeria.pdf

[20] Didia BC, Nduka EC, Adele O. Stature estimation formulae for Nigerians. J Forensic Sci. 2009; 54(1): 20-21.

[21] Okoro I, Agu G, Uloneme G. Stature prediction from foot length in a Nigerian population. J. of Expt. \& Clin. Anat. 2009; 8(1): 33 - 35.

[22] Egwu OA, Nto NJ, Bello EF, Egwu EO, Ukoha UU, Ajah D. Stature estimation from foot dimensions of an adult Nigerian population. Anatomica Karnataka. 2012; 6(2): 8-12.

[23] Ekezie J, Anibeze IP, Akpuaka C, Anyanwu E, Onwukamuche K, Uloneme C. Stature estimation using right digits and palm length in Igbo population, Nigeria. Annals of Bioanthropology. 2014; 2(1): 23.

[24] Chigbu UE. Fostering rural sense of place: the missing piece in Uturu, Nigeria. Development in Practice. 2013; 23(2): 264-277.

[25] Zeybek G, Ergur I, Demiroglu Z. Stature and gender estimation using foot measurements. Forensic Sci Int. 2008; 181(1-3): 54 el-5.

[26] Ibeabuchi NM, Okubike EA, Olabiyi OA, Nandi M E. Predictive equations and multiplication factors for stature estimation using foot dimensions of an adult Nigerian population. Egyptian Journal of Forensic Sciences. 2018; 8: 63.

[27] Alabi AS, Oladipo GS, Didia BC, Aigbogun (Jr) EO. Regression equations for stature prediction in Nigerian Hausas, Igbos and Yorubas from toe length and toe-length ratios. Anthropol. 2017; 5 (1): 176-181.

[28] Ansah EO, Abaidoo CS, Diby T, Tetteh J, Appiah AK, Atuahene OO, et al. A preliminary anthropometric study of height and sex determination using percutaneous ulnar and femoral lengths. Int J Anat Res. 2017; 5(1): 3638-3643

[29] Obikili EN, Didia BC. Foot dimension of a young Nigerian adult population. Port Harcourt Medical Journal. 2006; 1(1): 22-24.

[30] Dhaneria V, Shrivastava M, Mathur RK, Goyal S. Estimation of height from measurement of foot breadth and foot length in adult population of Rajasthan. Indian J Clin Anat Physiol. 2016; 3(1):78-82.

[31] Kim W, Kim YM, Yun MH. Estimation of stature from hand and foot dimensions in Korean population. J Forensic Legal Med. 2018; 55: 8792.

[32] Saharan RA, Arun M. Stature estimation from foot anthropometry in individuals above 18 years belonging to Indian demography. Journal of Medical Science and Health. 2015; 1(2): 25-29.

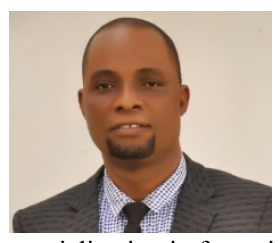

L. E. Oghenemavwe was born in Port Harcourt Rivers State of Nigeria on May 25, in the 70s. He attended the prestigious Government College Ughelli for his secondary education. He proceeded to the University of Port Harcourt Medical School where he Obtained PhD (distinction) in Anatomy with specialization in forensics and Microscopic Anatomy.

He is currently the Head Department of Anatomy, University of Port Harcourt, Nigeria and Lead Researcher in Human Variation and Identification. He is an Expert Anatomy lecturer with more than 15 years of teaching, research and administrative experience at the university level with consistent track record of motivating and inspiring students to pursue 
academic and personal excellence for entrepreneurial creativity. $\mathrm{He}$ is result-oriented and dedicated to management goals that help promote learning, organization success and community development.

Dr. Loveday is the leader of Anthropology Group of the Anatomical Society of Nigeria, member Society for Experimental and Clinical Anatomists, member Nigeria Association of Biological Anthropology. He was the recipient of the National Universities Commission award in 2012 for contribution to Medicine and Life Sciences in Nigeria. 